\title{
Assessment of herd management on organic and conventional dairy farms in the United States
}

\author{
K. E. Stiglbauer, ${ }^{* 1}$ K. M. Cicconi-Hogan,$\dagger^{1,2}$ R. Richert,$\ddagger^{1}$ Y. H. Schukken, $†$ P. L. Ruegg, $\ddagger$ and M. Gamroth ${ }^{*}$ \\ *Department of Animal Sciences, Oregon State University, Corvallis 97331 \\ †Department of Population Medicine and Diagnostic Sciences, Cornell Veterinary Medicine, Cornell University, Ithaca, NY 14853 \\ ‡Department of Dairy Science, University of Wisconsin-Madison, Madison 53706
}

\section{ABSTRACT}

The objective of this study was to evaluate management characteristics on organic and similarly sized conventional dairy farms located in New York, Wisconsin, and Oregon. Data from 192 organic farms (ORG), 64 conventional nongrazing farms (CON-NG), and 36 conventional grazing farms (CON-GR) were collected during farm visits and were size-matched and analyzed. The average lactation number of animals on ORG and CON-GR farms was 2.6 lactations, which was greater than that on CON-NG farms (2.3 lactations). A greater percentage of first-lactation heifers were found on conventional farms than on ORG farms. Facilities used by adult animals, including housing and milking facilities, did not differ among the grazing systems. Cattle on conventional farms were fed approximately twice as much grain as cattle on ORG farms and had greater milk production. Little difference was found for the average reported somatic cell count and standard plate count, suggesting that milk quality is not dependent on grazing system. Milking procedures were similar across all 3 grazing systems, indicating that an industry standard now exists for milking and that milk quality problems will need to be addressed with other management problems in mind. Although some disease prevention measures were commonly utilized on ORG farms, such as keeping a closed herd and having a written record of treatments administered to the animals, the use of outside support and vaccinations were found to be less prevalent on organic farms than on conventional farms. Key words: dairy, organic, management, comparative study

\section{INTRODUCTION}

Over the past $10 \mathrm{yr}$, the demand for organic agricultural products has increased rapidly in the United States and worldwide. Sales of organic foods have

Received June 18, 2012.

Accepted October 7, 2012.

${ }^{1}$ These 3 authors contributed equally to this publication.

${ }^{2}$ Corresponding author: kmc277@cornell.edu reached $\$ 25$ billion in the United States and account for approximately $3.7 \%$ of total US food sales. Organic dairy products comprise $15 \%$ of total organic sales, and organic fruits and vegetables account for $38 \%$ of total sales, making them the top 2 sectors of organic food (Organic Trade Association, 2010). From 2000 to 2008 , the number of certified organic cows in the United States increased from 38,196 to 249,766 (USDA Economic Research Service, 2008). Based on the current growth rate of organic food consumption, it is predicted that the demand for organically produced dairy products will continue to increase (Batte et al., 2007). The increase in the number of certified organic dairy animals and the associated production of organic milk products is consumer driven, as many consumers are concerned with animal welfare and the environmental impact of conventional dairy farming (Sundrum, 2001); however, scientific data on management methods and herd health on organic farms are needed to validate or refute these concerns.

The National Organic Program (NOP) of the US Department of Agriculture (USDA) defines US standards for the transition to organic production (USDA National Organic Program, 2011). From the starting point of a completely conventional dairy system, the land must be transitioned to organic status over the course of $3 \mathrm{yr}$ without the use of any substances prohibited by the NOP. In the third year, the dairy animals must be managed $100 \%$ organically and be fed a diet composed of only certified organic feed. All animals that will constitute the organic herd must be on the farm at the beginning of the third year of transition, with no additions from nonorganic farms during that year. Calves that are entering an organic farm must be raised organically from the last third of gestation (NOFA-NY, 2009). Animals certified as organic may not receive NOP-prohibited substances, including antimicrobials or synthetic reproductive drugs. Although some overlap exists between US and European organic standards, there are some key differences. Antimicrobials are allowed as a disease treatment on organic farms in the European Union (EU), with the involvement of and diagnosis by a veterinarian. Any animal given an 
antimicrobial must have their milk kept out of the tank or their meat kept from sale for double the withholding time compared with animals from conventional herds. However, these animals can return to the herd and do not lose their organic status (CEC, 1999). On organic dairy farms in the United States, animals or products from animals given NOP-prohibited substances may no longer be sold as organic, and these animals must then be removed from the herd. However, producers are prohibited from withholding necessary treatment from a sick or injured animal (USDA National Organic Program, 2011). Organic management in the United States therefore heavily promotes preventative measures, such as vaccination, to handle disease (Ruegg, 2009).

As of 2008, most organic dairies in the United States were former conventional farms that transitioned to organic management within the past $10 \mathrm{yr}$ (Ruegg, 2009). Organic farms receive a higher price for their milk, which has encouraged many smaller farms to transition to organic production. However, some economic analyses have indicated that net profits of conventional and organic farms in some regions are similar (Dalton et al., 2008; Cook et al., 2010); thus, more studies about the economic sustainability of organic dairy farming are needed. Because of the recent surge in the number of organic farms, the need for established best management practices and overall herd health information on organic dairy farms is growing, but the industry lacks sufficient scientific information based on contemporary organic practices. This lack of scientific information on best management practices is particularly true in the United States, as organic management has been studied in more detail on European organic farms (Nauta et al., 2006; Ellis et al., 2007; Padel et al., 2009; Bennedsgaard et al., 2010). Several studies have compared antimicrobial use and mastitis management on organic and conventional dairy operations in the United States (Zwald et al., 2004; Pol and Ruegg, 2007; Ruegg, 2009), but no large-scale studies have been conducted that investigate the broader healthcare practices and the resulting wellbeing of cows on size- and location-matched organic and conventionally managed herds.

The primary objective of this study was to assess health, management, and herd characteristics among size-matched conventional nongrazing farms (CONNG), conventional grazing farms (CON-GR), and organic dairy herds (ORG) across New York, Wisconsin, and Oregon.

\section{MATERIALS AND METHODS}

\section{Recruitment and Herd Selection}

A total of 192 ORG and 100 conventional (CON) herds were recruited between March 2009 and May 2011 from dairy herds located in New York (NY), Oregon (OR), and Wisconsin (WI). In the NY subset of farms, 1 ORG farm from Vermont and 1 CON farm from Pennsylvania (matched to a similarly sized NY organic farm within a 50-mile radius) were included because of their proximity to the NY border. Because of herd demographics within each state, herds were matched by dairy production system (ORG vs. CON) with differing ratios by state. The ratios were as follows: 3 ORG to 1 CON (NY), 1 ORG to $1 \mathrm{CON}$ (OR), and 2 ORG to 1 CON (WI). Recruitment letters were sent to producers in all 3 states. Organic herds were identified initially by listings from organic certifying organizations, county extension agents, and personal contacts. A list of potential CON herds was compiled by obtaining a list of licensed dairy farms from each state's department of agriculture. Recruitment letters for the study were sent to all ORG and randomly selected CON farms in the same county. Each recruitment letter included a participation reply postcard requesting further contact information and basic demographic information. Positive respondents were contacted by phone or mail to determine eligibility for the study. Nonresponders were sent multiple mailings to increase participation. In NY, 400 ORG farms were contacted through recruitment letters, with approximately 80 positive responses; in OR, 32 ORG farms were contacted, with 24 positive responses; in WI, 600 ORG farms were contacted, with 120 positive responses.

\section{Herd Inclusion and Exclusion Criteria}

To fulfill study entrance criteria, ORG farms had to have been certified organic and shipping organic milk for at least 2 full years before their participation in the study and have a minimum of 20 lactating cows. Conventional herds included in the study were required to have a minimum of 20 cows and must have been shipping milk for at least 2 yr. Farms with fewer than 20 adult cows were not included in the study because our goal was to assess management strategies on established commercial dairy operations, and including farms with fewer than 20 cows would open the study up to "hobby" farms. Conventional farms were within a 50mile radius of enrolled ORG herds and were matched based on herd size, characterized into 3 groups: 20 to 99 adult cows, 100 to 199 adult cows, and $\geq 200$ adult cows.

\section{Questionnaire}

The study questionnaire (UW Milk Quality, 2012; http://milkquality.wisc.edu/organic-dairies/projectcow/) was adapted from previously published surveys 
(Zwald et al., 2004; Pol and Ruegg, 2007). It was reviewed by professional questionnaire developers and tested before use with pilot ORG and CON dairy farmers at each site. Information regarding questionnaire format and specifics are listed in detail in Richert et al. (accepted). The Institutional Review Board at Oregon State University approved the use of human subjects for the questionnaire.

\section{Data Collection}

Data collection has been described in detail in Richert et al. (accepted). In brief, a single member of the study team conducted all interviews within each state. Before herd visits began, all study personnel were trained together on administration of the questionnaire and the scoring systems used in the study. In most herds, the individual directly responsible for animal health and farm management was interviewed. Farmers were asked to refer to all available records to ensure accuracy of answers. Recall was frequently limited to the $12 \mathrm{mo}$ before the herd visit or less. Questionnaire information addressed several questions of each of the following themes: animal health personnel, herd inventory, production, reproduction, housing, feed and water, milking procedures, routine procedures, disease definitions and treatment, mastitis, Johne's disease, veterinarian involvement, calves and heifers, and DHIA information (if applicable). Retrospective treatment data, including calf and adult cattle disease, mastitis, culling, vaccinations, and veterinarian use, were collected for the $60-\mathrm{d}$ period before the visit using on-farm records or farmer recall. The farmer was asked to record all herd health events that occurred in the 60 -d period after the herd visit on predefined recording forms. Farmers were also asked to take milk samples from cases of subclinical or clinical mastitis during the $60-\mathrm{d}$ prospective period. Prepaid mailers were left to return recording forms and milk samples. If no prospective data were received after the $60-\mathrm{d}$ period had lapsed, the farmer was called and reminded to send in the information.

Samples of bulk milk collected by study personnel were sent to Quality Milk Production Services at Cornell University (Ithaca, NY) and tested for foodborne pathogens (Salmonella spp., Listeria monocytogenes, Shiga toxin Escherichia coli), Mycoplasma bovis, bovine viral diarrhea virus, and Mycobacterium avium ssp. paratuberculosis (Johne's disease). Samples were sent by courier to Dairy One Cooperative (Ithaca, NY) and tested for milk quality including SCC, fat percentage, protein percentage, SPC, E. coli coliform count, and laboratory pasteurized count. Bulk tank SCC and SPC information were collected from 3 mo before the herd visit and compared with the collected sample to help ensure accuracy of gathered information. Prospective data forms and mastitis samples were returned to the investigators by the farmer after a reminder phone call. Individual quarter mastitis samples from WI and OR study herds were analyzed at University of WisconsinMadison's Dairy Science laboratory (Madison). Mastitis samples from NY herds were analyzed at Quality Milk Production Services at Cornell University.

\section{Statistical Analysis}

Study Variables. Dairy production system (ORG and $\mathrm{CON}$ ) and grazing information were combined to create a new explanatory variable, grazing system, which had 3 levels: (1) ORG, (2) CON-GR, and (3) CON-NG. Grazing was defined as herds in which $\geq 30 \%$ of the DMI of lactating cows was obtained from pasture during the grazing season. Outcome study variables were analyzed as continuous, binary, or categorical variables.

Continuous outcome variables (Table 1) were number of years operating a dairy farm, milk per cow per day $(\mathrm{kg})$, age of housing (yr), percentage of lactating cows that have milk segregated from the bulk tank and are untreated, mean reported SCC for the 3 mo before the herd visit $(\times 1,000$ cells $/ \mathrm{mL})$, calving interval in days (obtained from herd record systems or estimated by adding $60 \mathrm{~d}$ to the estimated lactation length), mean lactation number, percentage of first-lactation animals, number of days the animals had spent grazing in the past year, and the amount of grain fed per lactating cow per day $(\mathrm{kg})$.

Binary outcome variables (Table 2) were predominant breed (more than $50 \%$ of Holstein, Jersey, or other breed), written documentation of treatments, written documentation of herd health events, use of DHIA (defined as use of the full service, including milk quality, breeding, production, calving and inventory information), use of a dedicated calving area (use of a dedicated area, no dedicated area), entering replacement stock brought onto the farm in the past year, use of a quarantine unit at milking, use of a California Mastitis Test, use of automatic take offs, use of predipping, use of postdipping, use of gloves as part of a regular milking routine, use of a written milking routine, use of rotational grazing, regular use of a nutritionist to formulate ration, regular veterinary visits, utilization of vaccinations for cows (defined as yes if the farmer reported any specific vaccination for cows), utilization of vaccinations for calves (defined as yes if the farmer reported any specific vaccination for calves), use of footbaths on dry cows, use of footbaths on lactating cows, use of rotational grazing, and if cows are transferred to another farm. 
Table 1. Least squares means of continuous farm characteristics, herd performance indicators, and nutrition variables analyzed among conventional nongrazing (CON-NG; $\mathrm{n}=64)$, conventional grazing $(\mathrm{CON}-\mathrm{GR} ; \mathrm{n}=36)$, and organic $(\mathrm{ORG} ; \mathrm{n}=192)$ dairy farms ${ }^{1}$

\begin{tabular}{|c|c|c|c|c|}
\hline Variable & \multicolumn{3}{|c|}{ Grazing system } & $P$-value ${ }^{2}$ \\
\hline Mean lactation number & $2.3^{\mathrm{a}}$ & $2.6^{\mathrm{ab}}$ & $2.6^{\mathrm{b}}$ & $<0.001$ \\
\hline Number of years in dairy business & 27.9 & 23.7 & 24.1 & 0.099 \\
\hline Mean age of housing (yr) & 36.8 & 37.2 & 36.5 & 0.994 \\
\hline Milk per cow per day $(\mathrm{kg})$ & $27.9^{\mathrm{a}}$ & $24.5^{\mathrm{b}}$ & $19.5^{\mathrm{c}}$ & $<0.001$ \\
\hline Percentage of herd segregated from the tank & $1.0^{\mathrm{a}}$ & $1.0^{\mathrm{a}}$ & $4.0^{\mathrm{b}}$ & $<0.001$ \\
\hline Mean reported bulk tank SCC from previous 3 mo $(\times 1,000$ cells $/ \mathrm{mL})$ & 213 & 208 & 221 & 0.707 \\
\hline \multicolumn{5}{|l|}{ Nutrition and grazing } \\
\hline Grain fed $(\mathrm{kg} / \mathrm{d})$ & $9.0^{\mathrm{a}}$ & $8.8^{\mathrm{a}}$ & $5.2^{\mathrm{b}}$ & $<0.001$ \\
\hline Mean number of days spent grazing & - & $182^{\mathrm{a}}$ & $190^{\mathrm{b}}$ & 0.041 \\
\hline
\end{tabular}

${ }^{\mathrm{a}-\mathrm{c}}$ Means within a row with different superscripts differ $(P<0.05)$.

${ }^{1}$ The linear model always consisted of the variable of interest (grazing system), farm size category (0-99 adult cows, 100-199 adult cows, $\geq 200$ adult cows), and study site (New York, Wisconsin, Oregon). Multiple comparisons were assessed using the Bonferroni correction.

${ }^{2} P$-value for the continuous variables represents an $F$-test on the Type III sum of squares of the indicated variable across the 3 grazing systems. ${ }^{3}$ Estimated calving interval had the use of DHIA also forced into the model to correct for the estimation bias of those farms not on DHIA.

Categorical outcome variables (Table 3) were method used to breed cows (AI only, some natural service, all natural service), method used to breed heifers (AI only, some natural service, all natural service), mean reported SPC of 3 mo before the herd visit $(0-7,000$ cells $/ \mathrm{mL}$, 8,000-32,000 cells/mL, $\geq 33,000$ cells $/ \mathrm{mL}$ ), mean percentage of DMI from pasture across the previous grazing season for cows $(\geq 50 \%, 51-75 \%, 76-100 \%)$; mean percentage of DMI from pasture across the previous grazing season for heifers $(\geq 50 \%, 51-75 \%, 76-100 \%)$, number of milking units $(0-10,11-20, \geq 20)$, use of a blanket treatment at dry off (antimicrobial exclusively, internal or external sealant, a combination of antimicrobial and sealant treatments, other treatment, no treatment), and milking facility (double side pit parlor, flat parlor, tie stall or stanchion, other type of parlor). To determine how frequently a farmer used advice from an outside source, the following 3 variables were used to create the explanatory variable outside support score (OSS): (a) utilization of a nutritionist, (b) utilization of DHIA, and (c) utilization of regular veterinary visits. The OSS was additive, as a positive response for any of the OSS variables was given a single point, with a minimum score of 0 (no outside help from any of the given sources) to a maximum score of 3 (utilization of regular veterinary visits, DHIA, and a nutritionist).

Categorical herd characteristics that were included as explanatory variables in the analyses were: Grazing system, herd size category (20-99 cows, 100-199 cows, and $\geq 200$ cows) and site (NY, OR, and WI). All farms were included in the analyses of every variable, with the exception of the percentage of herds that transfer cows to another farm. Only farms in NY and WI were analyzed for this variable, as the question was not interpreted the same way by the OR investigator.

Statistical Procedures. All statistical analysis was performed using SAS version 9.2 (SAS Institute, 2008). PROC UNIVARIATE was used to analyze individual continuous variables and assess normality of the variable distributions. Variables with a non-normal distribution were categorized into 3 groups based on the 25th and 75th percentiles $(0-25,26-75,76-100)$. Statistical significance was $P \leq 0.05$ for all variables.

Associations between continuous outcome variables and grazing system were assessed individually by linear regression using PROC MIXED (SAS Institute, 2008) with class statements for grazing system, herd size category, and site. The regression model was formulated as follows:

$$
\begin{gathered}
Y=\beta_{0}+\beta_{1} \text { Grazing System } \\
+\beta_{2} \text { HerdSizeCategory }+\beta_{3} \text { Site }+\varepsilon,
\end{gathered}
$$

where $Y=$ continuous outcome variable, $\beta_{0}=$ intercept term, $\beta_{i}=$ regression coefficient, and $\varepsilon=$ error term. Herd size and site were corrected for in the models that analyzed continuous variables, as these were design characteristics. The exception to this was the estimated calving interval variable, which had the use of DHIA included into the model to account for the estimation bias of those farms not on DHIA.

Associations between categorical outcome variables and grazing system were assessed using PROC FREQ 
Table 2. Least squares means of binary nutrition and grazing information, milking procedures, and preventative management variables analyzed (\%; indicating positive response) among conventional nongrazing (CON-NG; $\mathrm{n}=64)$, conventional grazing $(\mathrm{CON}-\mathrm{GR} ; \mathrm{n}=36)$, and organic $(\mathrm{ORG} ; \mathrm{n}=192)$ dairy farms in New York, Wisconsin, and Oregon ${ }^{1}$

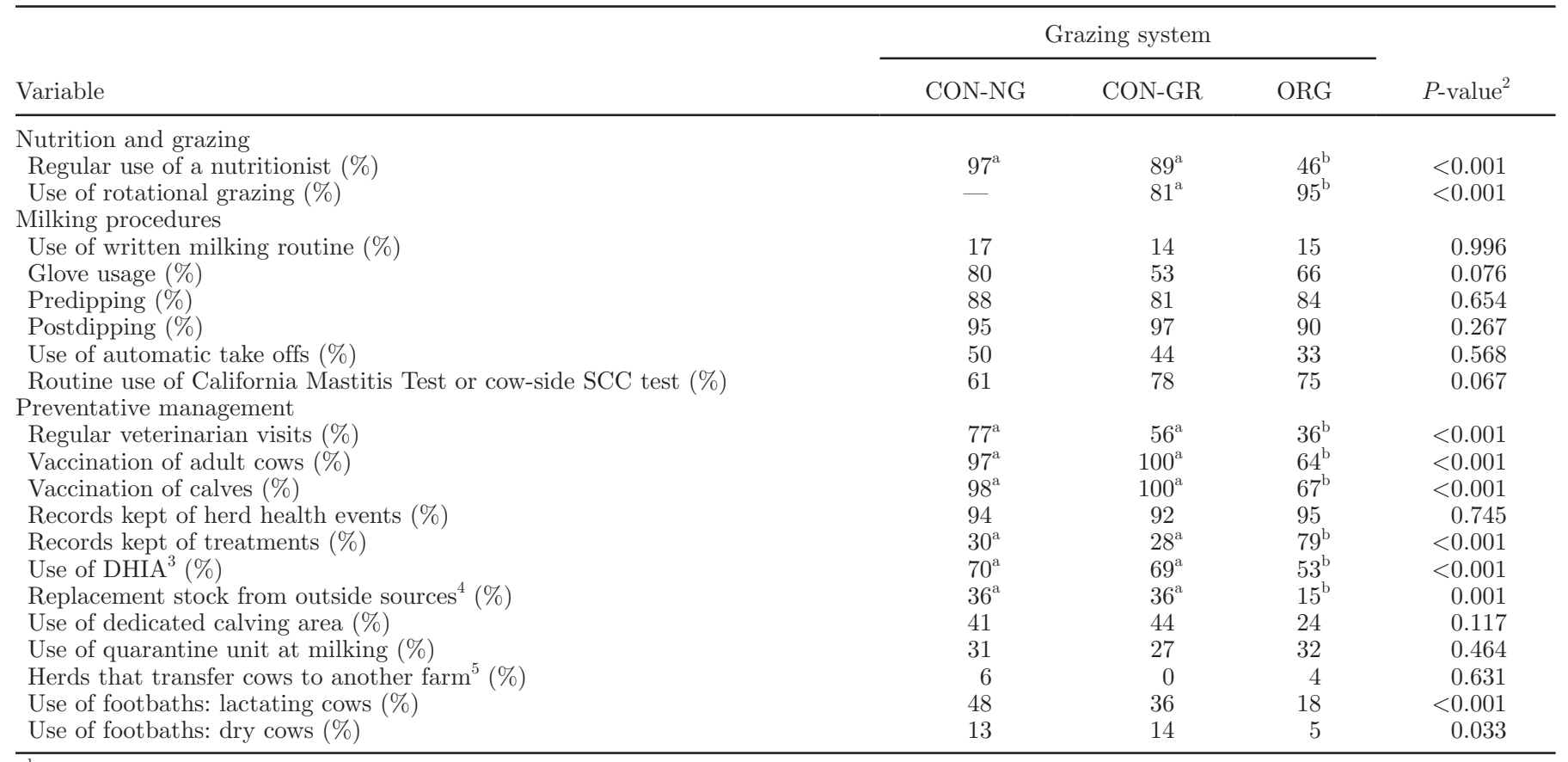

${ }^{\mathrm{a}, \mathrm{b}}$ Means within a row with different superscripts differ $(P<0.05)$.

${ }^{1}$ Multiple comparisons were assessed using the Bonferroni correction.

${ }^{2} P$-value for the binary variables represents an $F$-test on the Type III sum of squares of the indicated variable across the 3 grazing systems.

${ }^{3}$ DHIA is defined as use of the full service, including milk quality, breeding, production, calving, and inventory information.

${ }^{4}$ Analysis included information on weaned heifers and lactating cows only.

${ }^{5}$ Analysis included farms from New York and Wisconsin only.

(SAS Institute, 2008) by a chi-squared test. For these variables, herd size and site were not corrected for in the analysis. In case of statistical significance, dominant cells were identified using the contribution of each cell to the chi-squared statistic.

Associations between binary outcome variables and grazing system were assessed individually by logistic regression using PROC LOGISTIC (SAS Institute, 2008) with class statements for grazing system, herd size category, and site. The regression model was formulated as follows:

$$
\begin{aligned}
\ln \left[\frac{Y}{1-Y}\right] & =\beta_{0}+\beta_{1} \text { Grazing System } \\
& +\beta_{2} \text { HerdSizeCategory }+\beta_{3} \text { Site }+\varepsilon,
\end{aligned}
$$

where $Y=$ binary outcome variable, $\beta_{0}=$ intercept term, $\beta_{i}=$ regression coefficient, and $\varepsilon=$ error term. Herd size and site were corrected for in the model, as these were design variables.

For the continuous and binary outcome variables, the least squares means between the grazing systems were assessed using multiple comparisons with the Bonferroni correction. The multiple comparison was implemented using the PDIFF statement of SAS (SAS Institute, 2008). Values reported are least squares means.

To assess differences among farms that utilized grazing, a sub-analysis was performed with data from only CON-GR and ORG farms. The only outcome variables included in this analysis were the average number of days spent grazing, the use of rotational grazing, the mean percentage of DMI from pasture for heifers, and the mean percentage of DMI from pasture for adult cows.

The association between OSS and utilization of vaccination was assessed through logistic regression using the regression equation shown above for binary outcome variables. The association between OSS and average reported SCC was assessed through linear regression using the regression equation shown above for continuous variables.

\section{RESULTS}

\section{General Farm and Herd Characteristics}

The mean percentage of first-lactation heifers on the farm at the time of the visit was $37.3 \%$ on $\mathrm{CON}-\mathrm{NG}$ 
Table 3. Categorical farm characteristics, herd performance indicators, nutrition and grazing information, milking procedures, and preventative management variables (\% by category) analyzed among conventional nongrazing $(\mathrm{CON}-\mathrm{NG} ; \mathrm{n}=64)$, conventional grazing $(\mathrm{CON}-\mathrm{GR} ; \mathrm{n}=36)$, and organic (ORG; $\mathrm{n}=192$ ) dairy farms in New York, Wisconsin, and Oregon

\begin{tabular}{|c|c|c|c|c|c|}
\hline Variable & Level & \multicolumn{3}{|c|}{ Grazing system } & $P$-value ${ }^{1}$ \\
\hline \multicolumn{6}{|l|}{ Farm characteristics } \\
\hline \multirow{2}{*}{ Predominant breed } & $\geq 50 \%$ Jersey & 5 & 17 & 10 & \multirow{2}{*}{$<0.001$} \\
\hline & $\geq 50 \%$ Crossbreed or other breeds & 9 & 11 & 27 & \\
\hline Milking facility & Double side pit parlor & 38 & 47 & 32 & 0.751 \\
\hline \multicolumn{6}{|l|}{ Herd performance indicators } \\
\hline \multirow[t]{3}{*}{ Farms using natural service for heifers (\%) } & None & 56 & 44 & 34 & \multirow[t]{3}{*}{$<0.001$} \\
\hline & Some & 31 & 39 & 21 & \\
\hline & All & 13 & 16 & 45 & \\
\hline \multirow[t]{2}{*}{ Farms using natural service for lactating cows (\%) } & None & 78 & 69 & 49 & \multirow{2}{*}{$<0.001$} \\
\hline & Some & 20 & 17 & 31 & \\
\hline \multirow[t]{3}{*}{ Mean DMI from pasture: heifers } & $\geq 50 \%$ & - & 33 & 21 & \multirow[t]{3}{*}{0.058} \\
\hline & $\overline{51}-75 \%$ & - & 14 & 7 & \\
\hline & $76-100 \%$ & - & 53 & 72 & \\
\hline \multirow[t]{3}{*}{ Mean DMI from pasture: adult cows } & $\geq 50 \%$ & - & 69 & 51 & \multirow[t]{3}{*}{0.003} \\
\hline & $51-75 \%$ & - & 31 & 24 & \\
\hline & $76-100 \%$ & - & 0 & 25 & \\
\hline \multicolumn{6}{|l|}{ Milking procedures } \\
\hline \multirow[t]{3}{*}{ Number of milking units } & $0-10$ & 64 & 72 & 75 & \multirow[t]{3}{*}{0.509} \\
\hline & $11-20$ & 30 & 25 & 20 & \\
\hline & $>20$ & 6 & 3 & 5 & \\
\hline \multicolumn{6}{|l|}{ Preventative management } \\
\hline \multirow[t]{3}{*}{ Dry treatment ${ }^{2}$} & Blanket antimicrobial & 36 & 36 & 0 & \multirow[t]{3}{*}{$<0.001$} \\
\hline & Sealant & 9 & 25 & 4 & \\
\hline & Combination & 25 & 15 & 0 & \\
\hline
\end{tabular}

${ }^{1} P$-value for the categorical variables represents the $\chi^{2}$ test of the indicated variable across the three grazing systems.

${ }^{2}$ Sealant treatments included internal and external teat sealants; combination comprised antimicrobial with a sealant treatment; other treatments included dry treatment specific teat dip and alternative treatments.

farms, $33.9 \%$ on CON-GR farms, and $31.6 \%$ on ORG farms $(P=0.002)$, as shown in Table 1 . The mean lactation number for cows on the farm at the time of the visit was lower on CON-NG farms $(P<0.001)$, with a mean lactation number of 2.3 compared with 2.6 lactations on CON-GR and ORG farms (Table 1). The distribution of the mean lactation number of the different grazing systems also indicated a trend of younger cows on conventional farms and older cows on ORG farms, as illustrated in Figure 1. We observed no difference in the number of years spent farming among CON-NG (27.9 yr), CON-GR (23.7 yr), or ORG farmers $(24.1 \mathrm{yr} ; P=0.10$; Table 1$)$. The age of the primary housing facilities did not differ by grazing system $(P=$ 0.99; Table 1).

Holstein cows were the predominant breed $(\geq 50 \%)$ on all 3 grazing systems, with numbers of crossbred and other breeds on ORG and CON-NG farms being the dominant cells (i.e., in the statistical analysis, the cells containing that information was statistically significant for this variable), as $27 \%$ of ORG farms reported having primarily crossbred animals, compared with only $9 \%$ of crossbred CON-NG herds $(P<0.001$; Table 3$)$. Distribution of primary milking facility types was similar across the 3 grazing systems $(P=0.75$; Table 3$)$.

\section{Herd Performance Characteristics}

The estimated calving interval was similar among grazing systems $(P=0.56$; Table 1$)$. The mean milk per cow per day was significantly different among all 3 groups. Conventional nongrazing farmers reported a mean of $27.9 \mathrm{~kg}$, CON-GR farmers reported a mean of $24.5 \mathrm{~kg}$, and ORG farmers reported a mean of 19.5 


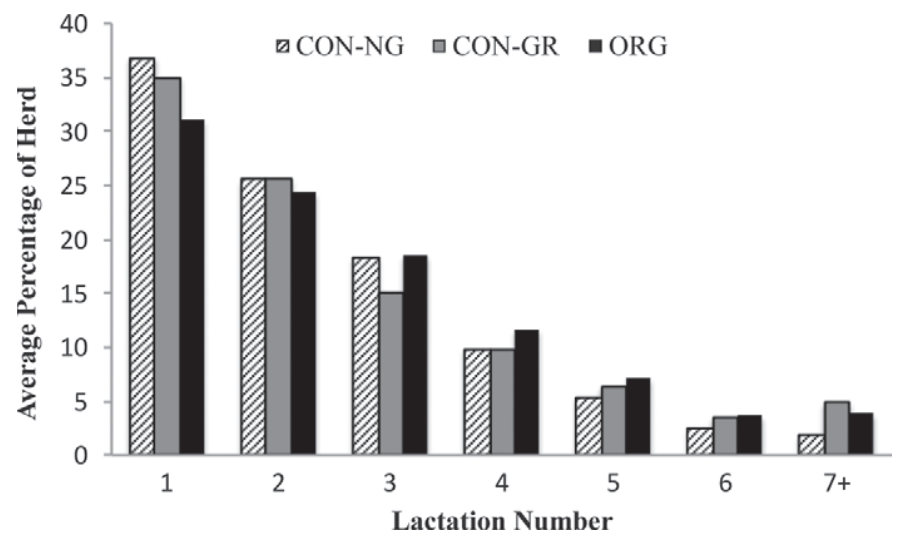

Figure 1. Mean percentage of all herds in lactation 1 to $7+$ for conventional nongrazing $(\mathrm{CON}-\mathrm{NG} ; \mathrm{n}=64)$, conventional grazing $(\mathrm{CON}$ $\mathrm{GR} ; \mathrm{n}=36$ ), and organic (ORG; $\mathrm{n}=192)$ dairy farms in New York, Wisconsin, and Oregon. Each bar represents the mean percentage of animals that fell into each lactation category of a given grazing system.

$\operatorname{kg}(P<0.001 ;$ Table 1$)$. Conventional nongrazing and CON-GR farms had a lesser percentage of lactating cows segregated from the tank $(1.0 \%$ for both $)$ compared with milk produced on ORG farms $(4.0 \%$; $P$ $<0.001)$. Reported bulk milk SCC was not different among the 3 groups, as shown in Table $1(P=0.71)$. The reported SPC category was not different based on grazing system $(P=0.35$; Table 3$)$.

As shown in Table 3, ORG and CON-GR farmers were more likely to use natural service for both nonlactating heifers and lactating cows compared with CON-NG $(P<0.001$ for both). Farmers on $45 \%$ of ORG farms reported using natural service exclusively to breed their nonlactating heifers compared with $13 \%$ of CON-NG farmers and $16 \%$ of CON-GR farmers. Farmers on only $2 \%$ of CON-NG farms reported using exclusively natural service for their adult cows, whereas $20 \%$ of ORG and $14 \%$ of CON-GR farmers reported using only natural service for breeding.

\section{Nutrition and Grazing}

Conventional farmers fed more grain than ORG farmers $(P<0.001$; Table 1$)$, with ORG farmers feeding approximately $45 \%$ less grain than CON-NG and CON-GR farmers. Organic farmers reported that their herds grazed for a greater number of days during the year before the herd visit $(190 \mathrm{~d})$ compared with CONGR herds (182 d; $P=0.041$; Table 1).

Conventional farmers were more likely than ORG farmers to use a nutritionist for ration and feeding advice $(P<0.001$; Table 2$)$. Organic farmers were more likely to use rotational grazing throughout the grazing season compared with CON-GR farmers (95 and 81\%, respectively; $P<0.001$; Table 2 ).
Organic and CON-GR farmers reported similar percentages of DMI from pasture for their nonlactating heifers $(P=0.058$; Table 3$)$. For their adult cows, however, ORG farmers reported a greater mean percentage of DMI from pasture than CON-GR farmers, as $25 \%$ of the ORG farms fell into the high DMI category compared with $0 \%$ of the CON-GR farms $(P=0.003)$.

\section{Milking Procedures}

Milking procedures and characteristics were similar across the 3 grazing systems. The use of a written milking routine, glove use at milking, the use of a predip or postdip solution at milking, the use of automatic takeoffs, and the use of a California Mastitis Test or other cow-side SCC test did not differ among grazing systems (Table 2). The number of units used during milking also did not differ among the grazing systems $(P=0.51 ;$ Table 3$)$.

\section{Herd Health Management Practices}

Preventative Procedures. Organic farmers were less likely to have regular veterinary visits $(36 \%)$ than CON-NG $(77 \%)$ or CON-GR farmers $(56 \%)$, as shown in Table $2(P<0.001)$. Only $64 \%$ of ORG farmers reported vaccinating adult cows compared with $100 \%$ of CON-GR and $97 \%$ of CON-NG farmers $(P<0.001$; Table 2). Similarly, $67 \%$ of ORG farmers reported vaccinating calves compared with $100 \%$ of CON-GR farmers and $98 \%$ of CON-NG farmers $(P<0.001$; Table 2$)$. We found no differences among CON and ORG farmers to keep written records of herd health events $(P=0.74)$, but ORG farmers were more likely to keep records of treatments given to animals compared with CON farmers $(P<0.001$; Table 2). Organic farmers were less likely to use the full DHIA service than CON farmers $(P<0.001)$, with $53 \%$ of ORG farmers reporting use of DHIA compared with 69 and $70 \%$ of CON-GR and CON-NG farmers, respectively (Table 2). Conventional grazing and CON-NG farmers were more likely to have entering replacement stock from outside sources $(36 \%$ for both) compared with $15 \%$ of ORG farmers $(P=$ 0.001 ; Table 2). No difference was found regarding the use of a dedicated calving area $(P=0.12)$ or a quarantine unit at milking $(P=0.46$; Table 2$)$. Organic farmers in NY and WI were not found to be any more likely to transfer cows to another farm compared with CON farmers $(P=0.63$; Table 2$)$. Footbaths were used more frequently on CON farms than on ORG farms for both lactating and dry cows $(P<0.001$ and $P=0.033$, respectively).

Dry-Off Treatment. The majority of ORG farmers reported no blanket dry-off treatment of any kind (94\%; 


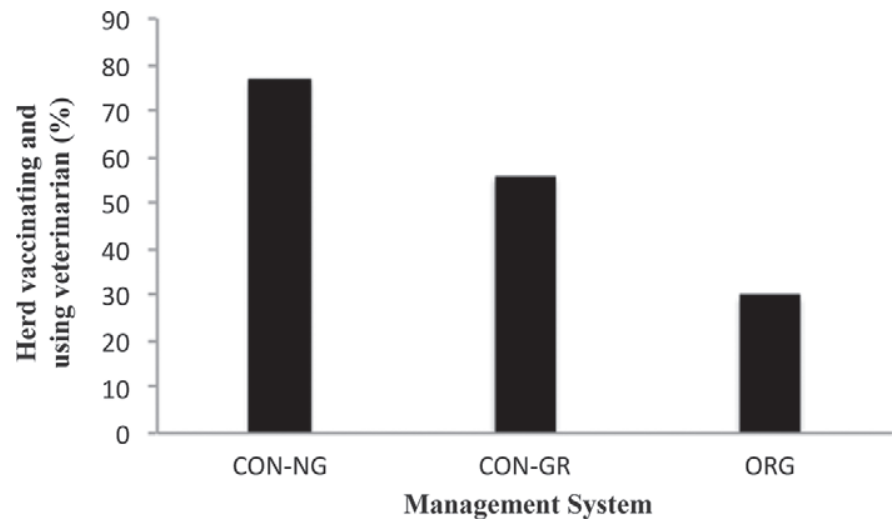

Figure 2. Percentage of conventional nongrazing (CON-NG; $\mathrm{n}=$ $64)$, conventional grazing $(\mathrm{CON}-\mathrm{GR} ; \mathrm{n}=36)$, and organic $(\mathrm{ORG} ; \mathrm{n}=$ 192) dairy farms in New York, Wisconsin, and Oregon that reported both vaccinating their adult cows and having regular visits from the veterinarian. Each management group adds up to 100\% (farms reporting no vaccinations are not shown). Significantly more CON-NG and CON-GR farmers reported utilization of both vaccination and a veterinarian compared with ORG farmers $(P<0.001)$.

Table 3). Conventional nongrazing farmers were equally likely to use traditional blanket intramammary antimicrobial treatment $(36 \%)$, a combination treatment of blanket intramammary antimicrobials and internal or external sealant products $(25 \%)$, or no blanket treatment $(30 \%)$, whereas the remaining $9 \%$ reported using a sealant product exclusively (Table 3). Conventional grazing farmers reported more variation in their use of dry treatments (Table 3), indicating use of traditional blanket antimicrobial treatment (36\%), combination therapy (15\%), sealant product only (25\%), and no blanket dry treatment $(22 \% ; P<0.001)$.

Use of External Support for Herd Health Management. Grazing system was associated with utilization of vaccinations and veterinarians $(P<0.001$; Figure 2). The percentages of farmers who reported no vaccination categorized by OSS were as follows: OSS = $0,60 \% ;$ OSS $=1,29 \% ;$ OSS $=2,17 \% ;$ OSS $=3 ; 1 \%$ (data not shown). The OSS was also associated with mean reported SCC, shown in Figure 3, as farms with a lower OSS had an overall higher SCC $(P=0.014)$. The OSS is associated with grazing system, as $95 \%$ of CON-NG farms and $80 \%$ of CON-GR farms scored 2 or 3 compared with $40 \%$ of ORG farms, as shown in Figure 4.

\section{DISCUSSION}

The primary objective of this study was to assess health, management, and herd characteristics of similarly sized conventional and organic dairy herds across New York, Wisconsin, and Oregon. This manuscript provides a concise, descriptive summary of some of the key differences and similarities among size-and regionmatched grazing systems. Although several studies have compared organic and conventional dairy management and disease in the United States (Zwald et al., 2004; Sato et al., 2005; Pol and Ruegg, 2007) and Europe (Ellis et al., 2007; Haskell et al., 2009; Langford et al., 2009), this is the first large-scale study in the United States to investigate management procedures in different parts of the country while matching herds based on size and geographical location. It is not straightforward to compare results from organic dairy studies in the United States to those in Europe, as standards for organic dairy production differ considerably (Ruegg, 2009).

This study was designed to enroll herds that were a representative sample of the organic dairy community in NY, WI, and OR to better understand the management practices of organic dairy farms on a national level. Approximately 30\% of eligible ORG herds in NY and WI, and $66 \%$ of eligible ORG herds in OR were enrolled in the study. Conventional herds in the study were included based on their interest, location, and approximate herd size. However, we recognize the possibility of selection bias in this study. Farmers were recruited through written letters and personal contacts,

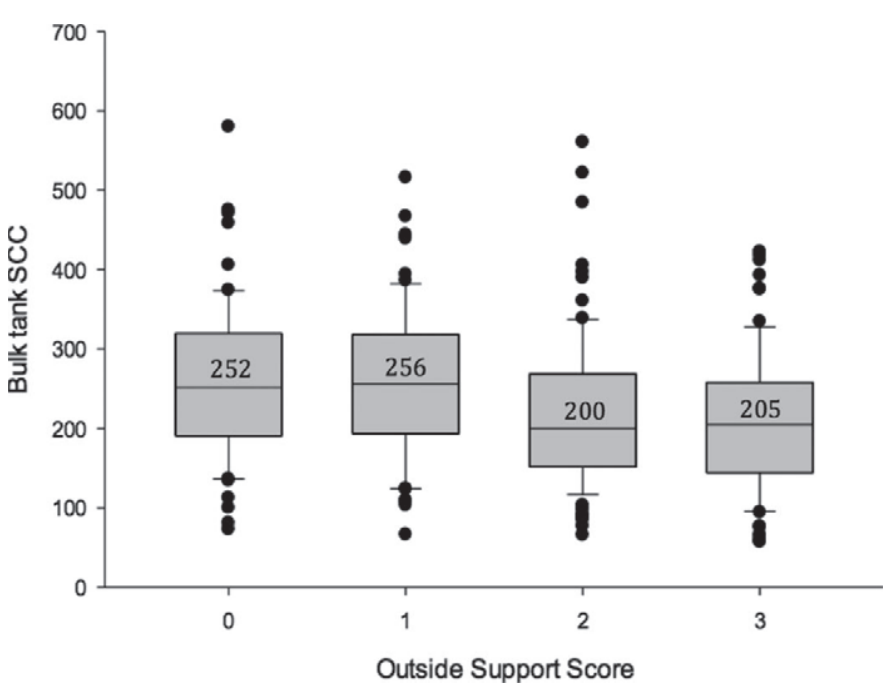

Figure 3. Average reported SCC $(\times 1,000$ cells $/ \mathrm{mL})$ of dairy farms in the study by outside support score (OSS). The OSS is additive, defined as (a) utilization of a nutritionist, (b) utilization of DHIA, and (c) utilization of regular veterinary visits. A positive response for any of the OSS variables was given a single point, with a minimum score of 0 (no outside help from any of the given sources) to 3 (utilization of regular veterinary visits, DHIA, and a nutritionist). Farms included in the analysis were categorized as conventional nongrazing (CON-NG; $\mathrm{n}=64)$, conventional grazing $(\mathrm{CON}-\mathrm{GR} ; \mathrm{n}=36)$, and organic (ORG; $\mathrm{n}=192)$ in New York, Wisconsin, and Oregon. Numbers reported in boxplots represent median SCC for each group. The OSS was also associated with mean reported SCC, with farms with a lower OSS having a higher $\operatorname{SCC}(P=0.014)$. 
1298

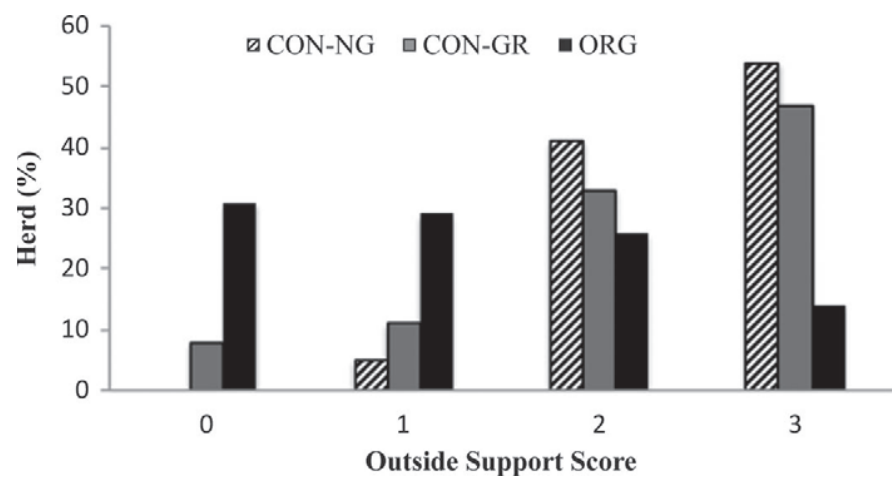

Figure 4. Percentages of conventional nongrazing $(\mathrm{CON}-\mathrm{NG} ; \mathrm{n}=$ $64)$, conventional grazing $(\mathrm{CON}-\mathrm{GR} ; \mathrm{n}=36)$, and organic $(\mathrm{ORG} ; \mathrm{n}=$ 192) dairy farms in New York, Wisconsin, and Oregon by each outside support score (OSS). The OSS is additive, defined as (a) utilization of a nutritionist, (b) utilization of DHIA, and (c) utilization of regular veterinary visits. A positive response for any of the OSS variables was given a single point, with a minimum score of 0 (no outside help from any of the given sources) to 3 (utilization of regular veterinary visits, DHIA, and a nutritionist).

with bulk tank testing and results of milk samples as compensation. Potentially, herds that did not have a high management standard or did not adhere closely to organic standards may have chosen not to participate in the study. Therefore, our study population of herds was somewhat self-selected, as with most survey research. Because this study was primarily a crosssectional study, we recognize that our research has several limitations. Further research that would allow investigators to follow farms over a longer period would be justified and useful.

The milk quality of organic farms compared with their conventional counterparts is a topic of interest for many scientists as well as consumers. The consumer perception that organic milk is of higher quality (Hill and Lynchehaun, 2002) is not supported by scientific studies. Little difference has been found in the bulk tank SCC between organic and conventional dairy farms (Rosati and Aumaitre, 2004; Zwald et al., 2004; Sato et al., 2005). It is generally accepted that bulk milk SCC is the primary indicator of milk quality in dairy herds and is associated with management practices on the farm (Dohoo and Meek, 1982; Barkema et al., 1998; Schukken et al., 2003). Our study results support these conclusions, based on the mean reported SCC and SPC from 3 mo before the herd visit. In our data, little difference existed in the milk quality of organic and conventional herds when matched by size and location.

When aiming to improve upon milk quality on dairy farms in general, milking procedures are generally considered a critical control point (Hutton et al., 1990; Fenlon et al., 1995; Jayarao et al., 2004). Our study showed that there was no relationship between grazing system and milking procedures, suggesting that an industry standard for milking exists on dairy farms that is unaffected by differences in production system. It also suggests that future troubleshooting on farms with a high SCC will need to be addressed through management techniques that are not specific to a production system. Previous work evaluating organic and conventional dairy farms suggested that, compared with conventional farms, organic farms typically house their animals in older housing during the winter months, which is considered a risk factor for disease (Ruegg, 2009). In this study population, we found no indication that age of housing varied based on grazing system when the herds were matched by region and size.

Although our data suggest a significant difference between the time (days) spent grazing between ORG and CON-GR farms, the difference was $8 \mathrm{~d}$, which is unlikely to be biologically significant. Conventional farmers fed more grain, whereas ORG cows and heifers obtained a higher percentage of DMI from pasture than CON-GR cows, which was also expected, because ORG regulations require a significant amount of DMI from pasture (NOFA-NY, 2009). With the higher expense of organic grain and other input costs, organic farmers may be feeding less grain as an economic management strategy; however, it is beyond the scope of this paper to fully explain the economic or other drivers of behavior in organic and conventional farms. Our results show that ORG farmers are more likely to use rotational grazing than CON-GR farmers. Organic farmers are well trained in the use of grazing methods and this may be reflected in their more likely use of rotational grazing methods. Organic farmers reported using footbaths less than conventional farms. Because grazing is used for a large part of the year, the reduced use of footbaths may be expected on organic dairies.

Our data indicate that ORG and CON-GR farms have higher percentages of older cows compared with CON-NG farms. Older cows are typically associated with increased risk of milk fever, mastitis, lameness, and other age-related illnesses (Dohoo et al., 1984). Our data support the common perception that organically managed dairy farms are more likely to have older cows. The results showed a $5 \%$ lower cull rate on ORG farms, which, although relatively modest, is still a significant difference concerning overall cull rates. A reason for the higher percentage of older animals on ORG farms may concern the purchasing of organically raised cows. Buying cows opens the herd to nonendemic diseases. Because of limited USDA-approved treatments on organic farms, the introduction of new animals poses a relatively greater risk compared with that on conventional farms, suggesting that the lower numbers 
of imported replacements may be a disease management strategy or, alternatively, the result of a limited supply of organic animals for purchase. The hesitation to purchase by ORG farms is further supported by the percentage of conventional farms that bring in replacement stock from outside sources, which is significantly higher than on ORG farms (Table 2).

Preventative management practices are important on any dairy farm, but especially on organically managed farms, because the availability of USDA-approved products to treat disease is limited. As demonstrated in our results, ORG farmers were more likely to keep written records than conventional farmers, although this is likely to be biased by grazing system, as organic regulations require keeping a written record of all treatments administered to the animals. Organic farmers in the study were more likely to segregate milk from the bulk tank compared with conventional farmers (Table 1). Although this may be a method to keep the SCC low, the greater proportion may also be a response to the need for milk for calves, as no organic milk replacer is currently commercially available. Blanket antimicrobial dry treatments reported among conventional farms were lower than expected, as previous studies reported $87 \%$ of farmers using dry treatment with antimicrobial infusion in Sato et al. (2005), and 88\% using treatment with antimicrobial infusion in the 1996 NAHMS study (USDA, 1996). In our population, only $60 \%$ of CONNG and $53 \%$ of CON-GR reported using blanket antimicrobial treatment with or without the use of a sealant (Table 3). This difference may be because the question presented to the farmer only asked about routine procedures for most or all cows in the dry cow group and was not inclusive of selective treatment of dry cows. Vaccinations are allowable by national organic standards and are generally considered an efficacious method to prevent various diseases in cattle (LeBlanc et al., 2006); however, only $64 \%$ of ORG farms in the study reported using vaccines on their adult cows compared with $97 \%$ of CON-NG and $100 \%$ of CON-GR farms. This trend was also present in vaccinations of dairy calves, as $67 \%$ of ORG farms in the study reported administering vaccines to their calves compared with $98 \%$ of $\mathrm{CON}-\mathrm{NG}$ and $100 \%$ of CON-GR. The difference in vaccine use at the farm level between ORG and CON dairy establishments is a point of interest and an area for future research.

Fewer ORG farmers reported regular veterinarian visits compared with CON farmers in this study (Table 3 ), a finding that is expanded further in Richert et al. (accepted). For the current study, we first evaluated the association between veterinarian use and vaccination on the farms. Figure 2 shows the percentage of each grazing system that reported both regular veterinar- ian use and vaccination; the data indicate that ORG farmers are less likely to utilize a veterinarian and vaccination. We expanded this analysis to consider the use of various outside resources as management tools and determine how they affected the percentage of farmers who reported vaccination. The variables considered were use of a nutritionist, regular veterinarian visits, and use of DHIA to calculate OSS. The OSS was associated with the average reported SCC, as farms with a lower OSS reported overall higher SCC (Figure 3). The least squares means of OSS were not different between CON-NG and CON-GR farms, which were more likely to score a 2 or 3 , but were both different from that of ORG farms, which were more likely to score a 0 or 1 (Figure 4). More research on the use of vaccines and other preventative measures in organic dairy farming would be of value, with a particular need for socio-economic research on the reasons for nonadoption of these common preventative practices in the organic community, which may be driven by philosophy and economics.

\section{CONCLUSIONS}

Consumer and scientific interests have increased demand for knowledge regarding milk quality, animal welfare, and management on organic farms compared with conventional farms. Our research indicated some profound differences between production systems but, overall, ORG and CON dairy communities were similar in nature, likely because most organic dairy farms in the study transitioned from conventional production. Organic and conventional dairy farms of the same size tend to follow similar milking procedures, be housed in facilities of comparable age, be managed by individuals with corresponding years of dairy experience, and have similar milk quality results. As expected, conventional farms tended to produce more milk, feed more grain, have longer calving intervals, and have younger cows than their organic counterparts. Organic farms were more likely to keep records of treatments given to the animals and have more nontreated animals segregated from the bulk tank than conventional farms. Organic farms reported a lower use of veterinary support, DHIA, nutritionists, and vaccinations compared with conventional dairies. Organic farms also report a lower use of AI on the farms. Further research on the nonadoption of preventative measures and the use of external resources for management support by the organic community should be investigated in the future.

\section{ACKNOWLEDGMENTS}

This study was supported by USDA NIFA Integrated Organic Program (grant \# 2008-51106-19463) "Impact 
of Organic Management on Dairy Animal Health and Well-being." We thank all the farms that participated in the study throughout New York, Vermont, Pennsylvania, Oregon, and Wisconsin. The authors also recognize the efforts of the laboratories at Quality Milk Production Services at Cornell University (Ithaca, NY), Dairy One Cooperative Inc. (Ithaca, NY), and the University of Wisconsin-Madison Milk Quality Laboratory (Madison).

\section{REFERENCES}

Barkema, H. W., Y. H. Schukken, T. J. G. M. Lam, G. Benedictus, and A. Brand. 1998. Management practices associated with low, medium and high somatic cell counts in bulk milk. J. Dairy Sci. 81:1917-1927.

Batte, M. T., N. H. Hooker, T. C. Haab, and J. Beaverson. 2007. Putting their money where their mouths are: Consumer willingness to pay for multi-ingredient, processed organic food products. Food Policy 32:145-159.

Bennedsgaard, T. W., I. C. Klaas, and M. Vaarst. 2010. Reducing the use of antimicrobials - Experiences from an intervention study in organic dairy herds in Denmark. Livest. Sci. 131:183-192.

CEC. 1999. Council Regulation No. 1804/1999 supplementing Regulation No 2092/91 on organic production. Off. J. Eur. Commun. 42(L222):1-28.

Cook, A. L., P. S. Heacock, G. K. Criner, and L. A. Bragg. 2010. Organic milk production in Maine: Attributes, costs, and returns. Maine Agricultural and Forest Experiment Station Tech. Bull., Orono, ME.

Dalton, T. J., R. Parsons, R. Kersbergen, G. Rogers, D. Kauppila, L. McCrory, L. A. Bragg, and Q. Wang. 2008. A comparative analysis of organic dairy farms in Maine and Vermont: Farm financial information from 2004 to 2006. Maine Agricultural and Forest Experiment Station Tech. Bull., Orono, ME.

Dohoo, I., S. Martin, and I. McMillan. 1984. Disease, production and culling in Holstein-Friesian cows II. Age, season and sire effects. Prev. Vet. Med. 2:655-670.

Dohoo, I. R., and A. H. Meek. 1982. Somatic cell counts in bovine milk. Can. Vet. J. 23:119-125.

Ellis, K. A., G. T. Innocent, M. Mihm, P. Cripps, W. G. McLean, C. V. Howard, and D. Grove-White. 2007. Dairy cow cleanliness and milk quality on organic and conventional farms in the UK. J. Dairy Res. 74:302-310.

Fenlon, D. R., D. N. Logue, J. Gunn, and J. Wilson. 1995. A study of mastitis bacteria and herd management practices to identify their relationship to high somatic cell counts in bulk tank milk. Br. Vet. J. 151:17-25.

Haskell, M. J., F. M. Langford, M. C. Jack, L. Sherwood, A. B. Lawrence, and K. M. D. Rutherford. 2009. The effect of organic status and management practices on somatic cell counts on UK dairy farms. J. Dairy Sci. 92:3775-3780.

Hill, H., and F. Lynchehaun. 2002. Organic milk: Attitudes and consumption patterns. Br. Food J. Hyg. Rev. 104:526-542.

Hutton, C. T., L. K. Fox, and D. D. Hancock. 1990. Mastitis control practices: Differences between herds with high and low milk SCC. J. Dairy Sci. 73:1135-1143.
Jayarao, B. M., S. R. Pillai, A. A. Sawant, D. R. Wolfgang, and N. V. Hegde. 2004. Guidelines for monitoring bulk tank milk somatic cell and bacterial counts. J. Dairy Sci. 87:3561-3573.

Langford, F. M., K. M. Rutherford, M. C. Jack, L. Sherwood, A. B. Lawrence, and M. J. Haskell. 2009. A comparison of management practices, farmer-perceived disease incidence and winter housing on organic and non-organic dairy farms in the UK. J. Dairy Res. 76:6-14.

LeBlanc, S. J., K. D. Lissemore, D. F. Kelton, T. F. Duffield, and K. E. Leslie. 2006. Major advances in disease prevention in dairy cattle. J. Dairy Sci. 89:1267-1279.

Nauta, W. J., T. Baars, and H. Bovenhuis. 2006. Converting to organic dairy farming: Consequences for production, somatic cell scores and calving interval of first parity Holstein cows. Livest. Sci. 99:185-195.

NOFA-NY (Northeast Organic Farming Association of New York). 2009. The Organic Dairy Handbook: A Comprehensive Guide for the Transition and Beyond. NOFA-NY, Cobleskill, NY.

Organic Trade Association. 2010. Organic industry survey summary. Accessed Mar. 30, 2011. http://www.ota.com/pics/documents/20 10OrganicIndustrySurveySummary.pdf.

Padel, S., H. Röcklinsberg, and O. Schmid. 2009. The implementation of organic priciples and values in the European Regulation for organic food. Food Policy 34:245-251.

Pol, M., and P. L. Ruegg. 2007. Treatment practices and quantification of antimicrobial drug usage in conventional and organic dairy farms in Wisconsin. J. Dairy Sci. 90:249-261.

Richert, R. M., K. M. Cicconi, M. J. Gamroth, Y. H. Schukken, K. E. Stiglbauer, and P. L. Ruegg. The role of the veterinarian on organic and conventional dairy farms. J. Am. Vet. Med. Assoc. (accepted).

Rosati, A., and A. Aumaitre. 2004. Organic dairy farming in Europe. Livest. Prod. Sci. 90:41-51.

Ruegg, P. L. 2009. Management of mastitis on organic and conventional dairy farms. J. Anim. Sci. 87:43-55.

SAS Institute. 2008. SAS/STAT ${ }^{\circledR} 9.2$ User's Guide. SAS Institute Inc., Cary, NC.

Sato, K., P. Bartlett, R. Erskine, and J. Kaneene. 2005. A comparison of production and management between Wisconsin organic and conventional dairy herds. Livest. Prod. Sci. 93:105-115.

Schukken, Y. H., D. J. Wilson, F. Welcome, L. Garrison-Tikofsky, and R. N. Gonzalez. 2003. Monitoring udder health and milk quality using somatic cell counts. Vet. Res. 34:579-596.

Sundrum, A. 2001. Organic livestock farming. Livest. Prod. Sci. $67: 207-215$.

USDA. 1996. Part III: Reference of 1996 Dairy Health and Health Management, USDA:APHIS:V.S. CEAH. National Animal Health Monitoring System, Fort Collins, CO.

USDA Economic Research Service (ERS). 2008. Organic production. Accessed Mar. 28, 2011. http://www.ers.usda.gov/Data/Organic/.

USDA National Organic Program (NOP). 2011. The Program Handbook: Guidance and Instructions for Accredited Certifying Agents and Certified Operations. Accessed Dec. 1, 2011. http://www.ams. usda.gov/AMSv1.0/nop.

UW Milk Quality. 2012. Project C.O.W. Accessed May 14, 2012. http://milkquality.wisc.edu/organic-dairies/project-c-o-w/.

Zwald, A. G., P. L. Ruegg, J. Kaneene, L. Warnick, S. J. Wells, C. Fossler, and L. W. Halbert. 2004. Management practices and reported antimicrobial usage on conventional and organic dairy farms. J. Dairy Sci. 87:191-201. 